University of Belgrade

Faculty of Philology

greta.goetz@fil.bg.ac.rs

\title{
CREATIVE COORDINATION: RELATING SLAVIC HERITAGE TO TECHNOLOGY-ENHANCED LEARNING
}

Summary: When seeking to develop the relational skills of interdisciplinarity (the ability to integrate knowledge and ways of knowing across several disciplines) while making use of new technology in the Serbian classroom, the narrative works of Serbian polymath thinkers of the early $20^{\text {th }}$ century may serve as relatable prolegomenal material. It will be shown how such figures possessed the epistemic fluency that is increasingly required by the digital age: Michael Pupin's "creative coordination" can be compared to the coordination of diverse ways of knowing. As such figures are also representatives of Slavic cultural heritage, it will further be asked how this heritage might be nurtured in the supranational technology-enhanced environment.

Keywords: constructive classroom, Slavic digital humanities, Michael Pupin, epistemic fluency, interdisciplinarity, technohumanism, philology, hermeneutics.

This paper considers the digital humanities in terms of how it is conceived in the interdisciplinary field of technohumanism. While not an ideal neologism, technohumanism is a useful term as it refers to the interdisciplinary humanistic field that is addressing the new arrangements of intellectual, social, political, and economic life in the Information Age (Davidson: 206-7). It invites critique while new media is being developed and used. Its driver is "an interactive, collaborative, participatory method of research and learning that capitalizes upon the power of new technologies and the customizing skills that youth bring to the college classroom today" (Davidson: 213). If youth is to be viewed as a resource (relational higher education indeed makes use of what students already know, see footnote 3 ), then the cultural capital that they also bring to the classroom may also be viewed as a skill to be developed. This paper seeks to address the interdisciplinary significance of the Slavic digital humanities in the digital domain that already relies on words (the domain of philology) as much as code and the creative coordination of precious materials. I take Michael Pupin as my model for the breadth and quality of learning, 
and his (online) autobiography as the prolegomenal text to my technology-enhanced courses on American Cultural Studies. He could serve as the introduction to any technology-enhanced course because of the rhetorical skill he employs to correlate a full range of topics.

Long before the age of the internet and big data, Michael Pupin in his autobiography called himself as "a goose in a fog" to describe how he felt as a new arrival at Castle Garden and at Cambridge before he learned his way (1949: 171, 178, 187, 207, 209). The question is how to keep that figurative goose alive in the fog layer of big data produced by the scientific positivism of technocratic Darwinism and the supranational forces that challenge cultural ways of knowing (Markoupolos 2010, ${ }^{1}$ Arnold 2006, Appadurai 1996).

I write "figurative goose" because the goose comes to us from an idiom particular to a specific culture, symbolizing respective world views and ways of being. In the spirit of Pupin, who defined different meaning making systems as "inseparable" (1927), it will be assumed that there is a space for the humanities (Slavic or otherwise) in the digital world.

The fact that Pupin did not see disparity between the so-called "two cultures" (Snow: 1956) of the humanities and science, or la querelle des anciens et modernes, is in part the product of his multidisciplinary education. But it was also made possible through what could be described as his breadth of spirit inclusive of dimensions that even Julia Kristeva tried to make relevant to her discussion on what Eastern European countries could bring of not only value but succor to the EU (2000: 111-162). I mention this to hint at the breadth of the type of Slavic texts to be used and interacted with online and in technology-enhanced classrooms.

1 I am referencing this short paper riddled with typos and not a more recognized text, written by an expert in the field, like Richard G. Olson's Scientism and Technocracy in the $20^{\text {th }}$ Century, because while articulating the threat of scientistic technocracy, it also speaks to the type of ecological knowledge that seeks to build relationships with others by taking a (Feyerabendian) holistic view. It is also a paper delivered in a Balkan context, hosted on a site that, while not strictly academic, does provide an example of a unique cultural representation on the internet - and an alternative (as it is thematically curated) to metablogs like rastko.rs. A holistic view is found in Pupin's "creative coordination" but is also found in Western thinkers who make alternative readings of science and culture (even James Clerk Maxwell could be cited in this context, see his argument with Tyndall in Goetz 2015). Again, though, this approach is not part of the Western master narrative, as pointed out in Markoupolis' assessment of the Bologna approach to engineering (which is his area of expertise). It is noted here that students themselves can want a 'quick formula' to get the job done, which is characteristic of technocratic efficiency but antithetical to both the task of learning and excellence in professionalism until the cause and consequences of the choices they make is explained to them: thence the relevance of the Markoupolis text that so briefly outlines what this explanation could look like. The Bologna approach to engineering (if we agree that Markoupolis' assessment is accurate - which I cannot speak to) may, after all, also be a product of the uncritical and ultimately reductionist times. 
The background to what I mean by "breadth" is found in the Byzantine legacy. It is relevant to note here - as we embark on discussion of Slavic digital literary spaces, that the Byzantine Empire, as Adrijana Marčetić has pointed out, can be considered one of the earliest world literary spaces, and perhaps the earliest European literary space (2018: 176). This "space" drew on ancient Greek models of learning but was infused with particular cultural and religious practices. It informed the education received by many $20^{\text {th }}$ century Serbian polymaths. The problem of positioning this particular legacy on the internet - to focus on this component of the digital humanities for a moment - is that the history and relevance of the Byzantine Empire has received insufficient attention from Western academics, whose scholarship, at least for the moment, still dominates the internet, because of English-language dominance (still above 50 per cent according to W3Techs.com) and also because of indexing.

It has been observed that: "The moment that media studies steps beyond the safe shores of the Anglophone media, the world suddenly becomes a much more complicated place" (Hobart 2010: 64-5). These unchartered waters are gaining attention in some Western scholarship, as indicated by the reference. They further demonstrate the meaning-making systems that the university student is to become aware of. Such awareness distinguishes the university graduate from the trade school graduate proficient in language for specific purposes: it promotes the meta-epistemological framework that has the potential to lead to meta-leadership. The Slavic digital humanities practiced at universities should at the very least point to this meta-level through consideration of an array of meaning- or knowledge-making systems, which is to say, contexts.

The role of the university is not merely to create users of the world, but to assist in the development of those with the techne to craft it. In other words, it is not enough to merely use digital technology: it is necessary to know something about it or at least know how to ask what is needed to understand it better. While this type of knowledge is not necessarily the same as specialized knowledge, it can demonstrate an awareness of the different contexts specific to ways of knowing about the world. Such awareness has been termed epistemic fluency, which technology-enhanced learning - by introducing an additional element to learning - has brought attention to. Epistemic fluency also has the potential to stimulate the breadth of knowledge more characteristic of the traditional learning models, which produced thinkers like Pupin and Milutin Milanković, than the technocratic specialization to have gained currency in the past few decades.

It is noted that classical learning models had as their apotheosis a fully-grown tree of knowledge. There was emphasis on the interconnection of subjects (meaning that the learner was not proficient in just one type of 
learning) and the order and categorization of ideas. It is this organizational structure, a characteristic of epistemic infrastructure, ${ }^{2}$ that can be compared to Pupin's creative coordination, which is suggestive of the tools with which to build constructive interrelations. Consider his words as they compare to figure 1 below, adapted from Mexican architect Antonio Toca Fernández's visualization of Jorge Luis Borges' "Library of Babel" (2009: 79) - itself an illustration of all of the knowledge representative of the universe.

Pupin writes that the broadest aspect of the life of man "is coordination, which eliminates the chaos from the activities of its countless molecules of life, and constructs the cosmos, the presence of which we feel in the internal world of our creative soul" (2005: 241-3). He further explains this in terms of interdisciplinarity: "in the language of science [this coordination] might be described as 'the climax of creative coordination'. Its cosmos is probably the ideal cosmos which the poets of ancient Greece had in mind" (2005: 241-3). What is more, each person was to be coordinated for the good of the whole social body: it is also political as it is activated by ideal democracy (1949: 384).

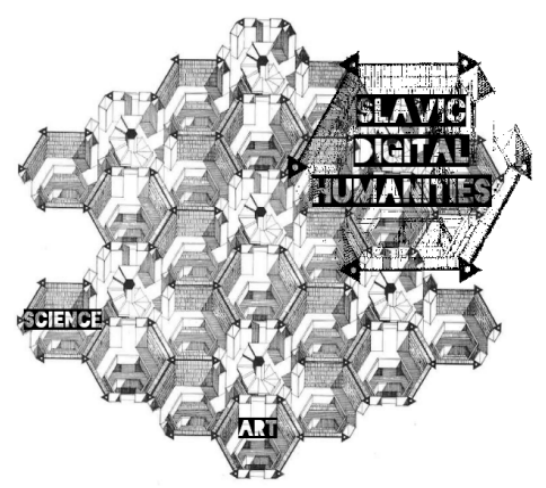

Fig. 1: Adapted from Antonio Toca Fernández, "La biblioteca de Babel: Una modesta propuesta," 2, no. 24, 2009, p. 79, http://www.uam.mx/difusion/casadeltiempo/24_iv_oct_2009/casa_del_tiempo_eIV_num24_77_80.pdf.

He explains that it is "gross abuse of language to speak of cold science" as such language creates a false opinion of science (1949: 380). Rather, science is intimately related to art:

2 Epistemic infrastructure comprises the basic conceptual, material and organizational structures and facilities needed for the operation of the 'knowledge enterprise' in a field and these fields are in turn coordinated in epistemic fluency (Markauskaite and Goodyear 2019 and 2017). 
No scientist can contemplate the mighty theme, the life of man, without pausing reverently and recalling Tennyson's well-known lines, dedicated to a tiny flower plucked from the crannied wall: 'I hold thee here, root and all, in my hand, / Little flower - but if I could understand / What you are, root and all, and all in all, / I should know what God and man is' (2005: 241-2).

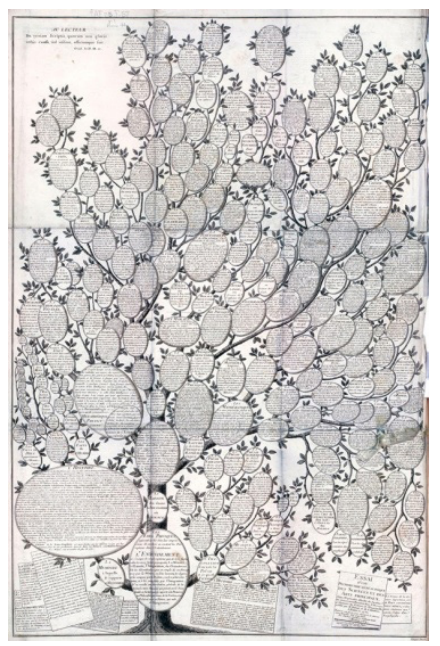

Fig. 2: Chrétien Frederic Guillaume Roth, "Essai d'une distribution généalogique des sciences et des arts principaux," Encyclopédie, Denis Diderot and Jean le Rond d'Alembert (eds.), 1751, https://encyclopedie.uchicago.edu/content/arbre-g\%C3\%A9n\%C3\%A9alogique.

If we may compare those words to figure 2 illustrating the tree of knowledge, or to Francis Bacon's taxonomy of human knowledge; to the "inseparable" systems comprising the epistemic infrastructure of Pupin's creative coordination, and to Fernández's illustration of Borges' bibliothecal universe, the problem of the context-specific nature of meaning making systems with their respective codes, knowledge bases, agendas, etc. can be seen as there are so many systems to keep in mind and relate to one another. This is a "problem" because if we are concerned with gaining a grasp on the 'bigger picture' (insofar as it is permitted to the human mind - a point not lost even on Francis Bacon in The Advancement of Learning and a lesson of hermeneutics, see Gadamer 2004: 556), it is not enough to have a grasp on a few disciplines as it is further necessary to synthesize this knowledge for the picture to be coherent. As Auerbach writes, how many scholars actually achieve synthesis given the "problematic ... ordering categories" which can 
be "too abstract and ambiguous" confirming the temptation to "master a great mass of material" (1969: 10)? He proposes instead to pursue topics that are "an organic inner part of the theme itself" (1969: 16).

What would the inner part of Slavic culture be? Do our students always have an answer? Can the Slavic culture be defined as a sum of parts? Can it be synthesized or contrasted with another culture?

To create space for such questions when guiding students as they collaborate with students from other cultures, prolegomenol texts can be selected that can set the course objectives and context and that can be referred to as the course progresses. Pupin's autobiography is one such text: providing his own very clear description of his view of his Slavic culture (intelligible enough to have been used in American elementary schools as required reading), in addition to demonstrating the breadth of interest in multiple ways of knowing and systems of meaning characteristic of epistemic fluency (again, intelligible enough to elementary school students: his answer to his question "what is light" is found in the physical, poetic cosmos). His autobiography is available in English on the extensive American-based internet library, archive.org - which I point out to illustrate the potential of interculturalism to cultural visibility.

But there are other Serbian thinkers among Pupin's contemporaries whose texts might also play a prolegomenol role in establishing a Slavic touchstone for technology-enhanced humanities learning. One such example is Nikolaj Velimirović, whose texts are available on various Christian (not just Serbian Orthodox) internet sites, in both English and Serbian, the former both the result of the longstanding impression he left on his host-cultures but also the result of the Serbian expat community. He also travelled extensively, interacting with other cultures and, readers' views on religion notwithstanding, it must be conceded that he contributed very significantly to Slavic, specifically, Serbian cultural legacy. To give just a few examples, although he was a bishop, he wrote intelligent works on Shakespeare (literature) and Nietzsche and Henri Bergson (philosophy), and in Nomology addressed the ideas of Max Planck and Thomas Edison (science), etc. (see Goetz 2009).

Both of these figures with a strong internet presence serve as examples of people who have enjoyed success abroad without compromising or losing Serbian (and, by extension, Slavic) attributes. Such attributes can be acknowledged without insisting that there is a right or wrong definition of what these attributes are. In fact, students can be asked to periodically reflect on what their definitions of Slavic attributes might be and whether they consider them relevant or not even in courses where this might not seem to be immediately relevant, such as in courses in medicine or economics where introducing an intra-disciplinary 
epistemic frame of reflexivity can be critical (for general examples, see Coles 1989: 107, 139).

It is being argued here that if we are working towards epistemic fluency - the apotheosis of digital studies (just as polymathy was the apotheosis of the classical education system), it is precisely by retaining any categories that might be controversial (or different, distant) that we can maintain a framework within which to refine the full range of analytical tools required by students in a world that is deeply in flux. If we cannot predict the jobs of the next twenty years, does it not stand that students should be equipped with more rather than fewer epistemic tools and contexts?

As philologists, we know that one of the most valuable skills to understanding is interpretation - and one of the critical tools of hermeneutics is distanciation, or the ability to be drawn away from oneself and one's opinions, beliefs - which is necessary if something else is to be understood (Ricoeur 1999: 86-8). This can also be described as a fusing of horizons: what takes place in communication is not just the expression that is something that is the interlocutor's or the listener's, but something that is common (Gadamer 2004: 390). Yet it must be emphasized that this disappropriation or distancing is as much a matter of self-understanding as it is a detour (Ricoeur 1999: 88) (this corresponds to the Stoic theory of appropriation): "All understanding is interpretation, and all interpretation takes place in the medium of a language that allows the [foreign/distant] object to come into words and yet is at the same time the interpreter's own language" (Gadamer 2004: 390, also see 449). For this reason, it is useful to make use of those Slavic digital humanities tools that contain something familiar as well as something new. This is why texts that contain the distance of the Slavic past, or (for Serbian students of the humanities) that address Serbian science, are useful. Examples that are taken from history and science have the potential to, respectively, teach: the effect of civics, the influence of great minds and fools, the forces of circumstance; the errors of application, the cautions of application (Barzun 1991: 77; Bacon 1876: 14-15). In sum, they teach how to be a better judge of life and politics and a better person (Barzun 1991: 77) - a better philosophe.

To close, I would like to consider Stanford University's digital project, "Mapping the Republic of Letters" (https://web.stanford.edu/group/toolingup/ rplviz/) which is a portal to the philosophes of the Enlightenment. This interactive resource allows users to: research individual writers; consider the geographical reach of interactions; compare correspondence, etc. What would it be like if a similar project were to consider the reach of interactions of the Byzantine Empire, and better, if there were a filter for the range of topics discussed - where they are woven together in epistemic synthesis? At this juncture, I will return to a text 
mentioned in passing earlier, and point out that when it comes to consideration of a full range of topics or epistemic categories, Slavic metaphysics has been presented by Julia Kristeva as a useful counterpart to problematic conceptions of individuality and freedom troubling the West (2000: 111- 162).

It is acknowledged that not everyone will agree with Kristeva - or with Pupin's description of creative coordination, which is ultimately guided by "divine breath" (n.d.). Atomists or relativists would further take issue with coordination, "which eliminates the chaos from the activities of its countless molecules of life, and constructs the cosmos" (2005: 241). And, obviously, the metaphysical background to Pupin's creative coordination distinguishes it from epistemic fluency in the way in which meaning and knowledge is ordered.

That said, where Pupin's creative coordination emphasizes that it is in each person's creative power to guide the whole social body of this complex life from that which threatens it (Pupin n.d.), the relational higher learning characteristic of epistemic fluency similarly emphasizes that individuals are to expand their understandings to work with others in an interrelated, shared infrastructure. ${ }^{3}$ Pupin's creative coordination can be compared with epistemic fluency where it is defined as coordinating different ways of knowing and constructing a consci(enci)ous self (Markauskaite and Goodyear 2018a).

On that note, it is up to us whether we can activate the creative coordination to protect the meaning-making system behind the "goose in the fog" from the meta-data of the fog layer - and from those who claim the possibility of a supranational cosmopolitanism that involves no hard work of self-reflexivity and no hard work of learning how to learn about the meaning making systems of others and ourselves.

\section{Sources and Literature}

Appadurai, Arjun. Modernity at Large. Minnesota: University of Minnesota Press, 1996. Arnold, Benedict. Imagined Communities. London, New York: Verso, 2006.

Auerbach, Erich. "Philology and 'Weltliteratur."' E. and M. Said (trans.). The Centennial Review, Vol. 13, No. 1 (Winter 1969): 1-17.

3 Markauskaite and Goodyear define standard higher education as comprising "expertdesigned services, students as customers of educational services, ... [performing] predefined tasks [with] predictable outcomes, quality [as the] responsibility of providers ... [on] a technological platform" vs. relational higher education which she describes as comprising "expert-enabled services, students as co-producers ... develop[ing] capabilities to co-create knowledge and experiences ... [in a] sociotechnical system". In other words, while the guiding forces for actionable knowledge(ing) do come from institutions and global knowledge culture it also comes from individuals (2018b: slide 41 ) - which brings us back to our opening point on technohumanism. 
Bacon, Francis. The Advancement of Learning. Oxford: Clarendon Press, 1876. https:// archive.org/details/baconadvancemen00bacogoog/.

Barzun, Jacques. Begin Here: The Forgotten Conditions of Teaching and Learning. Chicago and London: The University of Chicago Press, 1991.

Coles, Robert. The Call of Stories: Teaching and the Moral Imagination. Boston: Houghton Mifflin Company, 1989.

Davidson, Cathy N. "Humanities and Technology in the Information Age" in Oxford Handbook of Interdisciplinarity. Robert Frodeman, ed. Oxford, New York: Oxford University Press: 2010.

Fernández, Antonio Toca. Dibujo 2. "La biblioteca de Babel: Una modesta propuesta." Casa del tiempo 2, no. 24 (2009): 79. http://www.uam.mx/difusion/casadeltiempo/24_ iv_oct_2009/casa_del_tiempo_eIV_num24_77_80.pdf.

Gadamer, Hans-Georg. Truth and Method. London, New York: Continuum, 2004.

Goetz, Greta. "Nikolaj Velimirović's Views on Literature.” (Unpublished master's thesis.) 2009. Faculty of Philology, Belgrade University. Belgrade, Serbia.

-. "Intercultural Reading of the Autobiography of Michael Pupin: Science, Narration, and Nation." (Unpublished doctoral dissertation.) 2015. Faculty of Philology, Belgrade University. Belgrade, Serbia.

Hobart, Mark. "What Do We Mean By 'Media Practices?"” Theorising Media and Practice. Birgit Brauchler and John Postill, eds. New York, Oxford: Berghahn Books, 2010. 55-76.

Kristeva, Julia. "Europe Divided: Politics, Ethics, Religion" in Crisis of the European Subject. New York: Other Press, 2000, 111-162.

Markoupolis, Joannis N. "Engineering Education Perspectives. A Balkan Case Study" Thessaloniki, Greece. May 31-June 1, 2010. Aristotelian University of Thessaloniki. https://apeironcentre.org/logical-positivism-scientism-and-thehumanities-in-engineering-education/.

Mapping the World of Letters. Stanford.edu. https://web.stanford.edu/group/toolingup/ rplviz/.

Marčetić, Adrijana. After Comparative Literature. Institute for Literature and Art: Belgrade, 2018.

Markauskaite, Lina and Peter Goodyear. Epistemic Fluency and Professional Education. Dordrecht: Springer, 2017.

- . "Learning to Co-Create Actionable Knowledge Across Disciplines." 4 June 2018. epistemicfluency.com. https://epistemicfluency.com/2018/06/04/learning-to-cocreate-actionable-knowledge-across-disciplinary-and-professional-boundaries/.

- . "Quality Multiplied: Learning that Matters in a Runaway World." 26 November 2018. epistemicfluency.com. https://epistemicfluency.com/2018/11/26/qualitymultiplied-learning-that-matters-in-a-runaway-world/.

- . "Interdisciplinarity and Epistemic Fluency: What Makes Complex Knowledge Work Possible." 23 April 2019. epistemicfluency.com. https://epistemicfluency. com/2019/04/23/interdisciplinarity-and-epistemic-fluency-what-makes-complexknowledge-work-possible/.

Pupin, Michael. "Commencement Speech, Rochester," Columbia University Archives.

- . “Creative Coordination." Scribner's 82, no.2, August 1927. 
- . From Immigrant to Inventor. New York, London: Charles Scribner's Sons, 1949, https://archive.org/stream/fromimmigranttoi00pupi.

- . The New Reformation: From Physical to Spiritual Realities. New York: Cosmo Classics, 2005.

Ricoeur, Paul. From Text to Action. Evanston: Northwestern University Press, 1999.

Roth, Chrétien Frederic Guillaume. "Essai d'une distribution généalogique des sciences et des arts principaux," Encyclopédie. Denis Diderot and Jean le Rond d'Alembert, eds.1751, https://encyclopedie.uchicago.edu/content/arbre$\mathrm{g} \% \mathrm{C} 3 \% \mathrm{~A} 9 \mathrm{n} \% \mathrm{C} 3 \% \mathrm{~A} 9$ alogique.

Snow, C. P. "The Two Cultures", New Statesman, 6 October 1956, 413-414. http://www. newstatesman.com/cultural-capital/2013/01/c-p-snow-two-cultures.

W3Techs.com. "Usage of Content Languages for Websites." https://w3techs.com/ technologies/overview/content_language/all.

\author{
Грета Гец \\ Универзитет у Београду \\ Филолошки факултет \\ greta.goetz@fil.bg.ac.rs
}

\title{
КООРДИНАЦИЈА ИНТЕРКУЛТУРНОГ УМРЕЖЕНОГ УЧЕЊА НА ПРИМЕРУ СРПСКЕ УЧИОНИЦЕ
}

Сажетак: Баш као што зона наредног развоја није занемарена у успешној конструктивној учионици, културна искуства ученика не би требала бити занемарена у умреженој учионици. Потврђивање познатог студентима пружа ширину, они постепено развијају алате за изградњу конструктивних односа, које је Михајло Пупин назвао “креативном координацијом”. Остваривање потенцијала дигиталног хуманистичког образовања, које се пружа кроз технолошки напредак, захтева одређени степен епистемолошке флуентности коју показују српски научници почетком 20. века, попут Пупина. Ово такође подразумева да више српских текстова постане доступно на мрежи како би се олакшало коришћење и ангажовање. Педагогија заснована на повезаности која тежи „е-квалитету“ и ослања се на релациони дијалог и критичку рефлексивност (Beaty et. al.) потврђује континуирану важност интерпретативних вештина, па чак и разлучивања. Ове теме су имале истакнуто место у словенском културном наслеђу и доносе јединствену перспективу интеркултуралној комуникацији и контрастивној реторици.

Кључне речи: умрежено учење, дигитална хуманистика, епистемичка течност, српско наслеђе, херменеутика. 